\title{
Through an Activity Theory Lens: Conceptualizing service learning as 'boundary work'
}

\author{
JANICE MCMILLAN
}

$\mathrm{M}$ ichael Gibbons (2005) argues for the need to re-imagine the relationship between higher education and society and calls for the emergence of a 'new social contract'. In particular he highlights three elements of this new form of engagement: contextualization, boundary objects, and transaction spaces or boundary zones. It is here that my article is located: in the conceptualization of the 'boundary zone' at the nexus of higher education and society, with a focus on service learning as practice. In particular, I am interested in exploring how service learning can be conceptualized in new ways that might enable us to ask critical questions of the forms it takes, and the roles, identities and knowledge of those who try to make it happen.

The argument I make in this article is that in order to better understand the 'push and pull' of service learning, we first need to better understand what happens between the university and its external constituencies. In other words, what do they do together? And how do they do it? To understand this, we need to shift our 
unit of analysis - that is, what specific data we focus on to answer our research questions - from individualised practices towards the transaction space or boundary zone and develop conceptual tools to illuminate the complex social practices that occur at this nexus. Thus, in my case, the unit of analysis becomes the service learning 'activity system' (see later discussion on activity theory) - the activities that students and community members are jointly involved in as part of the service learning project.

Service learning is variously defined in the literature (see for example, Bringle \& Hatcher 1996; Morton \& Troppe 1996; Zlotkowski 1998). As a movement, it has a long history in the USA as part of the attempts by many higher education institutions to be more 'civically engaged' in searching for solutions to pressing social problems. However, as Waterman (1997) argues, it may be more useful to outline the major defining features of this form of educational practice than to pin the practice down to an exact definition. For Waterman, these features include:

- students learning and developing through actively participating in organised service experiences that meet actual community needs.

- experiences that are 'integrated into the students' academic curriculum' and provide opportunities for students to write, talk, and think critically and actively about the meaning and the learning from that experience.

- learning that is enhanced by extension beyond the classroom.

Service learning is a recently introduced practice in South African higher education. I thus begin the article with a brief overview of the South African national higher education context. I then present my conceptual framework, service learning as 'boundary work', drawing on the tools of activity theory. I show briefly how I used this framework to analyse two case studies at the University of Cape Town (UCT), which formed the basis of my recent $\mathrm{PhD}$ thesis, and finally, I end with some questions for future research and reflection on practice.

BACKGROUND CONTEXT: SOUTH AFRICA AND THE UNIVERSITY OF CAPE TOWN From the mid 1990s, and against the backdrop of our first democratic 
elections, South African national higher education policy began making strong arguments for a more 'responsive and engaged' higher education sector. The South African National Plan for Higher Education (2001) and the Education White Paper 3 (1997) put forward the following arguments regarding the role of higher education in contributing to social justice and economic and social life:

Higher education, and public higher education especially, has immense potential to contribute to the consolidation of democracy and social justice, and the growth and development of the economy ... The overall well-being of nations is vitally dependent on the contribution of higher education to the social, cultural, political and economic development of its citizens.

(CHE 2000, pp. 25-26)

These challenges and the need to re-think knowledge production in the context of the 'knowledge society' - knowledge as more socially relevant and 'generated in contexts of application' (Gibbons et al. 1994) - have been increasingly reflected in policy and legislation. This in turn has put new pressures on higher education institutions to respond to these calls for change. The National Commission on Higher Education (NCHE) (1996) has argued that there are a number of key responses required of institutions. These are reflected in White Paper 3 (1997) as challenges central to the transformation of the HE sector:

- increased participation

- responsiveness to societal needs

- cooperation and partnerships

Similar sentiments are identified by the Department of Education in the National Plan (2001), which include the following transformative goals for South African higher education:

the development and delivery of relevant curricula which contribute to providing high-level skills training which will 'develop professional and knowledge workers with globally equivalent skills, but who are socially responsible and conscious of their role in contributing to the national development effort and social transformation'. (Favish 2003, pp. 9-10)

One of the ways in which a number of publicly funded universities in South Africa took on this challenge particularly in relation to teaching 
and learning was via the national CHESP project - the CommunityHigher Education-Service Partnership Programme. From mid 1999 to the beginning of 2001, UCT, together with seven other universities, was the recipient of a Joint Education Trust (JET)-Ford Foundation planning grant as part of a national project to explore the potential of service learning in the context of community-higher educationservice partnerships (CHESP). The aims of the project were, amongst others, to develop service learning courses that allowed students to gain credit for academic learning in the context of community service and to empower disadvantaged communities through the engagement work. Central to these aims were the development of service learning partnerships.

Since the end of 2008, the CHESP project has become the responsibility of the Council on Higher Education (CHE). It is too early to tell what role it will play in continuing to support the development of service learning but it laid the foundation for many institutions in South Africa to re-think the ways in which teaching and learning can be more responsive to broader society. After this initial response to the challenge of transformation, it is now timely to rigorously look at what is involved in service learning practice so that it can be taken forward and built upon - as both pedagogy and a new way to think about university engagement in the broader society. To do this, requires new theoretical tools of analysis.

\section{Service learning as boundary WORK: A CONCEPTUAL LENS}

At the start of this article, I drew on the work of Waterman to identify a number of defining features of service learning. However, it is clear from reading the service learning literature that understanding this form of social practice often involves understanding more than the defining features. It is also involves understanding a whole range of complex and challenging relationships, values, processes, and interactions that go beyond what we would understand as the formal curriculum (Stanton et al. 1999; Cruz \& Giles 2000). In particular, Keith (2005) argues that putting 'difference' and 'situatedness' at the centre of our analyses and understanding is critical:

I want to look at the idea of situatedness and consider that a major task of service learning is not forming bonds of communion but reaching for understanding across difference in 
ways that enable working together towards goals of social justice. It is this understanding ... that is necessary for valorising the assets of the other and seeing difference itself as an asset rather than a deficit. (Keith 2005, p. 18)

Focusing research on the university-community interface or 'transaction space' would, I believe, be able to shed some light on service learning in a new way to take into account some of the complexities highlighted above. Linked to this, a number of authors have explored service learning as a form of 'border pedagogy' (Hayes \& Cuban 1997; Keith 1998; Skilton-Sylvester \& Erwin 2000; Taylor 2002), drawing largely on work in critical pedagogy and critical postmodernism (Anzaldúa 1987; Giroux 1992).

All of them argue that we need to develop new lenses to understand aspects of the service learning experience. They argue that the metaphors of 'borders', 'border-crossing' and 'borderland' are useful and important as a 'compelling starting point for describing and rethinking the nature of service learning' (Hayes \& Cuban 1997, p. 74). Hayes and Cuban quote Giroux as follows in support of this argument:

Border crossing serves as a metaphor for how people might gain a more critical perspective on the forms of domination inherent in their own histories, knowledge and practices, and learn to value alternative forms of knowledge ... Borderlands should be seen as sites both for critical analysis and as a potential source of experimentation, creativity and possibility. (Giroux 1992, p. 34, in Hayes \& Cuban 1997, p. 75)

The framework developed below adds to this body of theory by introducing the tools of activity theory and the language of boundary work.

\section{SERVICE LEARNING AND SOCIAL PRACTICE}

Given my understanding, following Vygotsky (1978), that learning is an inherently social practice, that is, we learn first through, and with, others before we internalize the learning as our own, I was initially drawn to social practice theories as a way of looking at service learning. It is important however, to note here that my thesis did not focus on student learning per se; rather, I focused on learning as a way to understand the social practices and activities between students and communities as they engaged with each other. 
In light of the above, I began with situated learning (Lave \& Wenger 1991) and the concept of 'social practice'. Following Lave and Wenger, I use social practice very broadly to emphasise the 'relational interdependency of agent and world, activity, meaning, cognition, learning and knowing' (Lave \& Wenger 1991, p. 50). From a situated learning perspective therefore, social practice is understood as a lens that puts an emphasis on:

the inherently socially negotiated character of meaning and the interested, concerned character of the thought and action of persons-in-activity. (Lave \& Wenger 1991, pp. 50-51)

Accordingly, learning, which in other frameworks might be viewed as individual, mental and non-social, is viewed as situated, collective and historically specific. It is this 'doing in a historical and social context' that gives structure and meaning to what we do. In understanding how this engagement takes place, the authors introduce the concept of a 'community of practice' to refer to the sustained engagement with others in joint practices over time. Following this, academic disciplines and their professional disciplinerelated bodies on the one hand, and community organisations and activities/practices, on the other, could each be viewed as a community of practice with their particular practices and ways of doing things. While a key point in situated learning is that people are members of multiple communities of practice - often simultaneously - I was looking specifically at the community of practice constituted by the engagement of students in their discipline-based community of practice with the community in their role as activists.

While situated learning - and a 'communities of practice' lens in particular - has a lot to offer and has been drawn on in theorising service learning (Wolfson \& Willinsky 1998; Castle et al. 2003), it also has limitations (Hay 1993; Lemke 1997; Hodges 1998; Daniels 2001). Many argue that there is lack of a coherent account of contexts that shape learning. This weakens it as a tool to use in exploring different communities of practice when they interact with others in a new setting. Secondly, a situated learning lens does not directly and explicitly develop a theory of power and power relations (Hodkinson \& Hodkinson 2003; Hodges 1998; Cooper 2005). Lastly, there are still no 'analytical tools' in this approach to facilitate the development 
of a more comprehensive theory of social practice and in particular, pedagogy.

ACTIVITY THEORY: DELINEATING THE 'UNIT OF ANALYSIS'

To address some of these critiques it is useful to return to the roots of situated learning and to the work of a number of post-Vygotskians. The particular strand I have drawn on is activity theory, evident in the work of Kozulin (1998) and Engeström and Miettinen (1999) in particular, where the unit of analysis is the activity system. While not offering a direct critique of communities of practice, Billett (2002) summarises the key differences between communities of practice and activity theory (AT) in ways that enabled me to see why the move from communities of practice to activity theory was important for my purposes. He argues:

Whereas communities of practice may be seen as the manifestation of particular situational factors that constitute a social practice, AT (Leont'ev, 1981) assists in identifying and understanding these factors [and their interrelationship]. AT holds that human actions are the product of social practices that are historically and culturally constituted. Some AT perspectives focus on historical and cultural contributions to human activity, including the sociogenesis of knowledge (for example, Leont'ev 1981; Cole 1998), whereas others focus on how situational factors shape human actions (such as Engeström 1996). The latter, in particular, assists in delineating what comprises a social practice and identifying the factors that constitute that practice. (Billet 2002, p. 85; emphasis added)

My use of the theory has been in this latter area, that is, focusing on how situational factors shape human actions. The rest of this section is focused on developing this understanding further.

For Engeström and Miettinen (1999), activity theory provides a very useful starting point in defining what is being researched - in other words, what the unit of analysis is. In this case, it is the activity system, a 'flexible unit of analysis' that enables us to look in different directions and with different levels of 'magnification' to answer the questions that puzzle us (Russell 2002). Through this lens, learning, teaching and social responsiveness can be viewed as activities that involve people and objects interacting in complex ways.

Russell argues that learning in an activity theory framework is 
not about the internalisation of discrete information or even skills by individuals; it is 'expanding involvement over time', social as well as intellectual, with other people and with the tools available in their culture. Engeström (1996) argues for 'three generations' of activity theory. In first generation activity theory there are three essential elements in any activity system: subject/s, object/s and tools (Russell, 2002). The subjects are individuals or subgroups engaged in an activity. The object is the 'raw material' on which the subject brings to bear various tools, for example, the 'object of study'. What is important to understand is that the object is more than just raw stimuli: it is a 'culturally formed object with a history, however short or long' (Russell 2002, p. 69). In any activity system, the motive is linked to 'object' as it shapes the overall outcome of the activity. Tools, both material and / or conceptual (Cole 1996), are understood as things that mediate subjects' action upon objects: they mediate or facilitate subjects doing things. Examples could include a concept, a computer, or a text. In service learning such tools might include texts, student questionnaires and other artefacts needed in order to learn in the context of a particular service learning course. It can be represented as follows below.

Figure 1

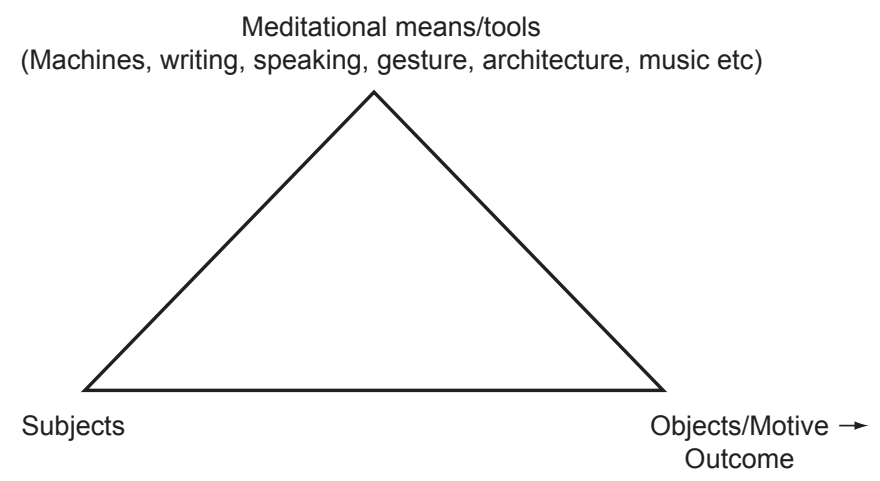

For the second generation, Engeström expands the framework to examine systems of activity at the macro level. The importance of this shift is that it foregrounds interrelations between the individual subject and his/her community of which he/she was a member. The community is the broader or larger group interacting in the activity and of which the subject/s is a part. The division of labour refers to the fact that in any activity there are always power relations and different roles are evident, often causing contradictions in the system. The 
rules operating in any activity are broadly understood as not only formal and explicit rules governing behaviour but also those that are 'unwritten and tacit', often referred to as norms, routines, habits, values and conventions (Russell 2002; Engeström1996). Figure Two captures it below.

Figure 2

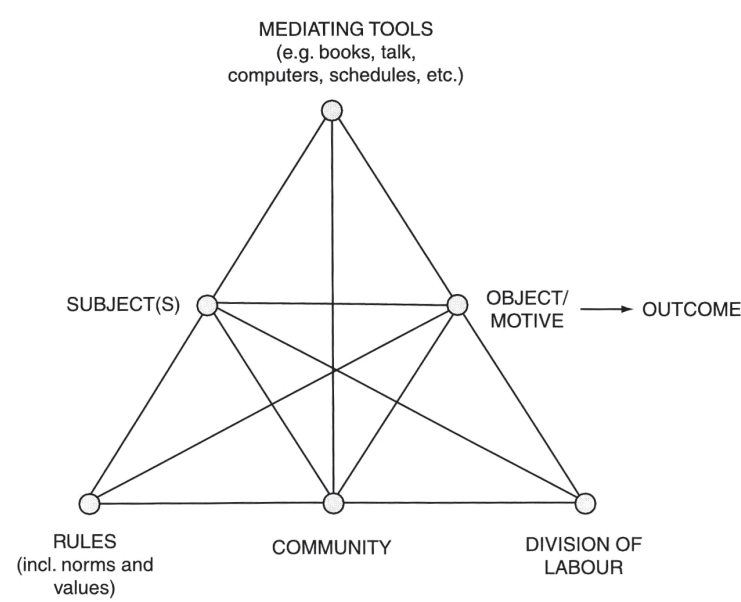

Third generation activity theory is aimed at providing tools and concepts that can enable us to understand and explore multiple viewpoints, value systems and 'networks of interacting activity systems' (Daniels 2001, p. 91; emphasis added), where contradictions highlighted by contested activity system objects emerge. In other words, two intersecting activity systems each have an identifiable object, which, as they work together on a common project, becomes a transformed object. The outcome of this is object three, the result of intersecting activity systems. It is represented below.

Figure 3

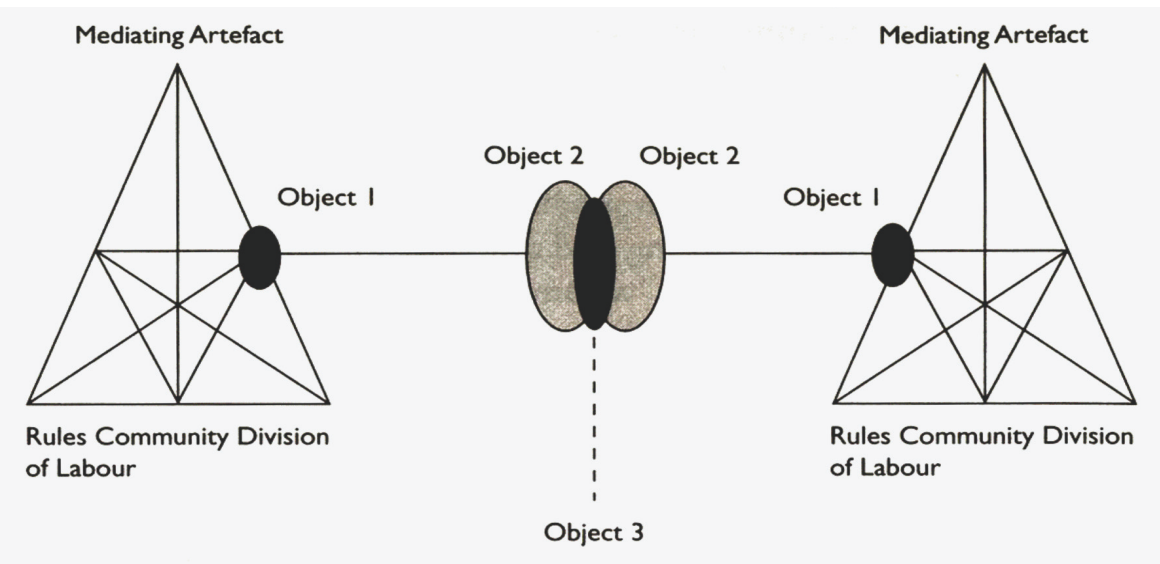


While I have been influenced by third generation activity theory, I have instead argued for two communities of practice interacting via one activity system and engaged in joint activities (McMillan 2008). It is only at the intersection - or boundary - with each other, that these communities of practice become one system and only through their activities together do the elements of the system get constituted. The activity system does not exist outside of the service learning activities; the activities act to constitute the system. In addition, my data in both cases indicated that the activity system constituted by the service learning does not generate one transformed object through its activities, as discussed by third generation activity theory; rather, distinct, albeit linked, objects remain. I discuss this issue further below.

In what ways does this framework assist us in developing a new language of analysis for service learning as a form of social responsiveness? Activity theory illuminates two key features of service learning that I have not seen discussed in other studies in the service learning literature. These are what I call in the first instance an expanded community and in the second, a dual (but interrelated) object. Introducing these two dimensions elaborates and takes further the notions of 'border pedagogy', 'borderland' and 'border-crossing' highlighted earlier by other service learning researchers.

Firstly, the 'expanded community': service learning involves an expanded, more diverse community than the traditional universitybased one consisting of students and educators. The community in service learning also includes an outside community. Communities, and the respective activity systems of which they are a part, represent different ways of engaging with the world, different histories with specific tools of mediation, and different kinds of knowledge and ways of knowing, all of which can challenge students, and thereby the activity systems, in significant ways. As noted by Russell (2002), the community element of an activity system has a significant impact on all the other elements in the system.

The second feature, a dual (but interrelated) object, refers to the fact that there are both learning and service goals to be achieved through service learning. Third generation activity theory outlined above, talks of the possibility of a 'contested object' across two activity systems when they interact with each other. However, I have re- 
interpreted this as a 'dual (but interrelated) object' in service learning. As I argued above, the service learning activity system only gets constituted when the university and community come together with their dual purpose - service and learning. This then translates into a dual (but interrelated) object of service and learning, rather than one transformed object. However, while clearly different, service and learning are inseparable, as it is through the service that the students learn, and it is through the learning that service gets rendered. Hence the dual (but interrelated) object. This sets up an inherent tension in service learning which impacts on the other dimensions of the activity system. I look at how this happens in two service learning cases after first turning to the last piece of the conceptual frame: service learning as 'boundary work'.

LANGUAGE OF THE BOUNDARY: ZONES, TOOLS AND WORKERS

Building on the activity theory frame, we need three more concepts: boundary zones, boundary objects, and brokering. These are drawn from the work of Star and Griesemer (1989), Bowker \& Star (1999), Wenger (1998) and Tuomi-Gröhn and Engeström (2003) amongst others.

In my work, I have used 'boundary zone' to refer to the activity system located between two communities of practice. Tuomi-Gröhn and Engeström (2003) argue that while such spaces are generally places of challenge, contestation and playing out of power relations, they can also be potential sites for new learning opportunities and new knowledge. And because such zones are the places where each community of practice reflects its own discourse, structure, norms and roles, elements from both systems are always present.

These relations and activities are mediated by tools of mediation or 'forms of reification' around which communities of practice organise their interconnections (Wenger 1998). Tools can be psychological (for example, a concept) or material (for example, a computer, a questionnaire); they have histories and are bound up in practices. In a boundary work frame, we need to understand tools as potential 'boundary objects' (Bowker \& Star 1999), that is, tools that might serve to coordinate the perspectives of various communities linked through joint activities. Bowker and Star argue that to the extent that they belong to multiple practices, tools of mediation represent 
the nexus of perspectives and practices and carry the potential of becoming boundary objects. This can only happen however, if through them, various perspectives can be coordinated. In other words, on their own and outside of a specific context, a tool is not inherently meaningful or powerful but when put to use in a specific context, it can take on very strong, often contestable, meanings. An example here could be a questionnaire: on its own it is not necessarily powerful but put to use in a specific context as a means of gathering information, it becomes very powerful and even contested.

Finally, specific roles and identities are important in understanding boundary work. In developing this frame I was interested in focusing on the actors who facilitate the activities across the boundary zone. These are the 'brokers' (Wenger 1998) or 'boundary workers' as I prefer to call them: agents who assist participants make new connections across activity systems, enable co-ordination and, if experienced, open up new possibilities for meaning and therefore learning (Wenger 1998). It is a complex role as it involves 'processes of translation, co-ordination and alignment between perspectives' (Wenger 1998). In order to influence the development of a practice, to mobilise attention and to address conflicting interests - in other words, to assist with learning by introducing elements of one community of practice into another - requires legitimacy on both sides of the boundary. In particular, I believe that we need to understand the skills, values, and knowledge required by academics to do this work successfully, as they are often the most centrally placed potential boundary workers. I reflect on some of this in the next section.

SERVICE LEARNING AS BOUNDARY WORK: TWO CASE STUDIES

Activity theory is a useful tool in analyzing contradictions and tensions between components of a system in order to change the system (Engeström 1996), and it is used in this way in much educational research. While I did not set out to use activity theory to change practice in my own research, I did use it to illuminate the nature of service learning as social practice. Inherent in this approach, is therefore identifying the key contradictions in the service learning activity system. These I identified as follows: 
- the (expanded) community-rules-(dual) object/outcome = discourses 'rubbing up against each other' $=$ disruptions in the boundary zone

- the (expanded) community-tools-(dual) object/outcome $=$ struggles over tools of mediation $=$ struggles over boundary objects

- the (expanded) community-division of labour-(dual) object $/$ outcome $=$ challenges to roles, identity and agency $=$ complex role of boundary workers

What this represents is the observation that in boundary work, rules, tools and division of labour are not constant and static. Indeed, they need to be negotiated and are often challenged; they shift and are sometimes completely transformed because of the two features noted above: the expanded community and dual (but interrelated) object. To illustrate these arguments, I will draw briefly on two case studies in my PhD study where this framework was developed.

My first case study involved students on a fourth-year MBChB Primary Health Care/ Public Health community-based block, a compulsory block offered by the School of Public Health and Family Medicine within the Faculty of Health Sciences at UCT. It is a compulsory part of the degree students take when qualifying as medical doctors in South Africa. The MBChB is an undergraduate degree over six years, including a seventh year of internship in order to qualify. This block comprises eight weeks in which students are on site in the community, three to four days per week. In the particular project I observed, students were engaged in a project with the South African Domestic Servants and Allied Workers Union (SADSAWU), focusing on occupational health and safety. Students completed epidemiological research with the workers for their public health component and then, based on their findings, ran a workshop with union members on occupational health and safety for the health promotion part of the block.

The second case study involved third-year Environmental and Geographical Sciences (EGS) students doing a human geography course. This involved a research and mapping project with a community-based organisation, the Valhalla Park United Civic Front organization (VPUCF) in Valhalla Park, a neighbourhood of Cape Town. In this case study the project involved collecting data 
(quantitative and qualitative) on the lives of people living in backyard shacks in Valhalla Park. ${ }^{1}$ The students went on four site visits where they worked with the VPUCF. Their service work was aimed at collecting mapping data for the VPUCF to negotiate with the City of Cape Town for better housing. The students then presented their findings to both students and VPUCF members. In both cases, my main data sources were:

- my own field notes observing student activities in the field

- interviews with academics and educators involved in the two courses

- student reflective journals

Based on the framework developed above, my analysis revealed that in each of the two activity systems, the two communities of practice, represented by the students on the one hand and their community partners on the other, reflected quite different rules, discourses (Gee 1990) and norms. In both systems, these rules were disrupted and challenged in the service learning course. An example drawn from one of the medical students' journals illustrates this well. He captures his feelings waiting for the domestic workers to arrive for the interviews:

It was happening again. There we were sitting in the hot sun ... waiting, waiting, yet again! Was it really so difficult to be on time? I wonder what the excuse is going to be this time? Would there even be an excuse? The frustration had been building up all week. Nothing had been going according to plan and time was running out. Why would anyone want to belong to a union? Was this the way other unions functioned?

Medical students for the duration of their training live a very unique and artificial existence compared to almost anyone else. We thrive on structure, pressure and fear. Take any one of these variables out of the equation, and we are totally lost. We constantly feel the need to be in control of whatever situation we find ourselves in. It is what we are being trained to do. In medicine, there are so many variables. It is impossible to control all of them. But we have to be in control of as much as we can as a way of compensating for those factors that are beyond our control. (Student $\mathrm{H}$, journal entry 1 )

\footnotetext{
${ }^{1}$ The term 'backyard shack' is one of many (for example, bungalow, Wendy house) used to describe the houses erected in the yards behind principal houses in a neighbourhood. The relationships between the house owners and backyard shack dwellers are complex and beyond the scope of this article.
} 
The challenge here is how to use this reflection as a learning experience and to value the different discourses. Second, I observed how the students and their community partners challenged the tools in the activities; in other words, there were 'struggles over tools of mediation'. An example in the EGS case was where the main activity system tool, a questionnaire, was challenged. Not only did the EGS students learn about the VPUCF and the community by administering the questionnaire, the VPUCF also had a big stake in the tool: they themselves had designed it. In complex ways therefore, this enabled them to use it for their own purposes. For example, at times they decided who needed to answer it based on their need for particular voices to be heard. It also meant that the students had less control over its content. One of the EGS students reflects this lack of control in discussing her discomfort at some of the questions they had to ask:

There was one question I remember on that survey which I didn't like asking, which was, 'If they didn't have any facilities for a toilet, whether they used a bucket?' I didn't like asking that. I thought it was a bit putting them on the spot and making them feel very uncomfortable. I know that they agreed to put those questions down but some of them I felt to be a bit imposing ... We were the ones experiencing it so I felt that it wasn't any use in going to Susan (the university lecturer) to ask. I don't think making those kinds of decisions was going to in any way jeopardize the survey. We collected all the data that was necessary. It was just that one question that we decided not to ask. (Student D1, interview, 19 January 2006)

While the student changed this question both she and her partner received comments the lecturer about this in their final report. By doing this, Susan thus reinforced the dominant and powerful role of the VPUCF in the students' learning. Tools thus have potential to act as boundary objects (Bowker \& Star 1999), with meaning on both sides of the boundary; however they need to be given credibility and positioned as such by both communities.

Third, contesting rules and challenging tools led to shifts in roles and division of labour. Power relations were challenged in both cases as new identities and forms of agency emerged. An example of this is during the workshop in the MBChB case where the workers challenged students' knowledge and authority in interesting ways: 
The whole workshop then took another turn when one of the domestic workers started acting out. A volunteer worker was asked for by student $\mathrm{H}$ to demonstrate picking up a basket to see whether they were doing 'it correctly'. One of the workers then exaggerated the role of picking up a basket and made fun of the role-play including the student who was running it. Student $\mathrm{H}$, a male student, then started demonstrating another role-play on ironing, showing the technique. While this is going on, [a domestic worker] gets up to do a little ironing skit in the corner. One of the other domestic workers said, as if she felt sorry for the student 'ok, I get your point, wow!' Felicia [one of the workers] then said that picking up a basket is difficult - for the 'fuller person - she can go halfway down but I am not sure if she can come up again!' One of the other domestic workers put it like this: 'jou maag kom in tussen jou bene [your stomach comes in between your legs] - ok, then you must tuck your tummy in'. There was laughter from both students and workers. (Field notes, 17 October 2004)

These pieces of data demonstrate the complex practices that develop in service learning and the ways in which rules, tools and division of labour can be disrupted and challenged in significant ways. In order to make sense of these practices, and to work towards practices that can deal with these differences in the boundary, I will conclude this section by outlining some questions that might be asked of such practices going forward.

Firstly, in working towards a better understanding of engagement processes and the zone in which they occur, we can ask:

- What is the nature of the 'interface', the 'boundary infrastructure', the 'transaction zone' in service learning/social responsiveness? What are the rules that operate here?

Answering this question could assist service learning researchers/ practitioners better understand the nature of the expanded community and its impact on the system. Additional questions include:

- In what ways is the boundary zone 'contradictory' or dangerous? And for whom?

- In what ways is the boundary zone important as a transformative space in higher education? How does it shape the nature of social responsiveness partnerships? 
Second, there is the issue of the tools of mediation. We need to consider what the role is of the tools of mediation we wish to use in our other social responsiveness activities. The question we can ask here is:

- Are the tools of mediation used in our service learning/social responsiveness 'boundary objects'? Can they inhabit multiple contexts at once, and have both local (within one community of practice) and shared meanings in this 'boundary practice'?

By designing them for 'boundary work', we are providing an opportunity to enrich both the learning as well as the service dimension of service learning, that is, the dual (but interrelated) objects of such a practice. Additional questions are thus:

- If our tools are not boundary objects, what will it take to design them as such?

- What impact do such tools have on service learning pedagogy?

Third, it is important to consider the role of the brokers or boundary workers. In order to better understand this role, we could ask:

- Who are the boundary workers in service learning/social responsiveness? Why do we see them as boundary workers?

An important first step in understanding this role is to identify the key people who play it. It might be obvious in some cases but not in others. It could include academics, community members, or students. As Wenger (1998) argues, boundary workers, for a whole range of complex reasons, are equipped with various kinds of knowledge and experiences and various degrees of power. It is important therefore to ask some additional questions:

- What are the knowledge, values, attitudes and authority required to play this role of boundary worker successfully?

- What are the challenges in playing the boundary worker role?

The example of one such 'boundary worker' in the Health Sciences Faculty at UCT indicates how important it is to think about what it takes to play this role successfully and whether more traditional academics necessarily have such backgrounds. Anna was a university-based and paid community Site Facilitator who 
worked with the MBChB students on their service learning projects largely due to her background in working with other community organisations in an education and research role. She says Site Facilitators:

... need to be up-dated [sic] with the debates in how you need to understand what $[. .$.$] research requires of the student.$ You need to be able to speak in the [university] environment and the community environment. You need to understand project planning and how to guide students through the project planning. You need to be able to function and interpret information across different learning approaches. Before you secure the project you need to speak about sample size, people accessing it and numbers and all of those things. You need to know what it means for the project if you do or don't secure certain things, and you won't unless you have a little bit of an understanding of research methodology. (Interview, November 2004)

Despite this knowledge however, it is important to note that the Site Facilitators were never considered academics in this role. One of the key challenges therefore in taking this work forward in South Africa (and I imagine elsewhere too) is to get recognition for the multiple knowledge sources that boundary workers draw upon when doing boundary work in higher education. Universities, if they are to serve as 'boundary institutions' (Hall 2003) and contribute to the public good, need to take up this challenge - and soon.

\section{Conclusion}

Gibbons (2005) has talked about the importance and challenges of working at the boundary of higher education and society:

Boundary work needs to be facilitated and managed and to do this specific knowledge and skills are required ... engagement as a core value will be evident in the extent to which universities do actually develop the skills, create the organisational forms and manage tensions that will inevitably arise when different social worlds interact. It is by commitment to resolving these tensions ... that universities will be able to demonstrate that they have embraced engagement as a core value ... [T] e embrace this form of engagement entails that universities themselves be prepared to participate in those 
potential transaction spaces in which complex problems and issues will be initially and tentatively broached. (Gibbons 2005, pp.11-12)

This article set out to discuss a framework for understanding and addressing some of these challenges. In order to do this, I argued firstly that we need to shift our unit of analysis from individualised practices towards the transaction/boundary zone and the social practices that take place here between very different constituencies: the universities and the communities with whom they engage. Through the lens of activity theory, I argued that service learning as a social practice has two inherent features that need to be made visible in order to develop our understanding of this form of social responsiveness. These are an expanded community (students, lecturers and community members) and a dual (but interrelated) object (learning and service). These two features have important implications for the other elements of the activity system and help to explain many of the challenges and complexities posed by this work. I showed this through some of the data from my study.

In conclusion, I strongly believe we need to see service learning as engaging differing strengths, knowledge and practices. The implications for UCT, and other higher education institutions engaging in this kind of work, is therefore to develop robust, relevant and critical ways of researching, developing and critiquing these practices. In order to facilitate this, we need to see different knowledges, voices and experiences as central to these processes. To return to Keith (2005), we need to see/imagine difference as an asset rather than a deficit because it is this that we need to harness in our social responsiveness. Hopefully, the tools introduced in this article can enable us to focus in on, and better understand, the nature of practices at the boundary where the 'knowledge of differently positioned people' intersect through social responsiveness practices such as service learning.

\section{REFERENCES}

Anzaldúa, G 1987, Borderlands/La Frontera: The new mestiza, Aunt Lute Books, San Francisco.

Billett, S 2002, 'Workplaces, communities and pedagogy: An activity theory view', in M Lea \& K Nicoll (eds), Distributed learning: Social and cultural approaches to practice, Routledge/Falmer \& Open University Press, London, New York. 
Bowker, G \& Star, S 1999, Sorting things out: Classification and its consequences, MIT Press, Cambridge, MA.

Bringle, R \& Hatcher, J 1996, 'Implementing service learning in higher education', Journal of Higher Education, vol. 67, no.2, pp. 221-239.

Castle, J Osman, R \& Henstock, V 2003, 'Coupling “school experience” with community service: A case study', Education as Change, vol. 7, no. 1, pp. 3-20.

CHE (Council on Higher Education, South Africa) 2000, Policy report: Towards a new higher education landscape: Meeting the equity, quality and social development imperatives of South Africa in the twenty-first century, Pretoria, South Africa.

Cole, M 1996, Cultural psychology: A once and future discipline, Harvard University Press, Cambridge, MA.

Cole, M 1998, 'Can cultural psychology help us think about diversity?', Mind, Culture and Activity, vol. 5, no. 4, pp. 291-304.

Cooper, L 2005, 'Towards a theory of pedagogy, learning and knowledge in a trade union context: A case study of a South African trade union', unpublished PhD thesis, School of Education, Faculty of Humanities, University of Cape Town.

Cruz, N \& Giles, D 2000, 'Where's the community in service learning research?', Michigan Journal of Community Service Learning, Special Issue Fall, pp. 28-34.

Daniels, H 2001, Vygotsky and pedagogy, Routledge/Falmer, London, New York.

Department of Education (DoE) 1997, Education White Paper \#3: A programme for the transformation of higher education, Government Gazette 386 (18207), no. 15.

Engeström, Y 1996, Perspectives on activity theory, Cambridge University Press, Cambridge.

Engeström, Y \& Miettinen, R 1999, 'Introduction', in Y Engeström, R Miettinen \& RL Punamäki (eds), Perspectives on activity theory, Cambridge University Press, Cambridge.

Engeström, Y, Miettinen, R \& Punamäki, RL 1999, (eds), Perspectives on activity theory, Cambridge University Press, Cambridge.

Eyler, J 2002, 'Stretching to meet the challenge: Improving the quality of research to improve the quality of service learning', in SH Billig \& A Furco (eds), Service learning through a multidisciplinary lens, Information Age Publishing, Greenwich, CT.

Favish, J 2003, 'Monitoring the quality of higher education: The case for making contributions to development central to considerations of quality', paper presented at Quality Assurance in higher education conference, University of the Western Cape, July.

Gee, J 1990, Social linguistics and literacies: Ideology in discourses, Falmer, London.

Gibbons, M, Limoges, C, Nowotny, H, Schartzman, S, Scott, P \& Trow, M 1994, The new production of knowledge, Sage, London.

Gibbons, M 2005, 'Engagement with the community: The emergence of a new social contract between society and science', paper presented at the Griffith University Community Engagement Workshop, South Bank campus, Queensland, Friday 4 March 2005.

Giroux, H 1992, Border crossings: Cultural workers and the politics of education, Routledge, New York.

Hall, M 2003, 'Boundary institutions: Universities and social change', unpublished paper, University of Cape Town.

Hay, K 1993, 'Legitimate peripheral participation, instructionism, and constructivism: Whose situation is it anyway?', Educational Technology, vol. 33, no. 3, pp. 33-38.

Hayes, E \& Cuban, S 1997, 'Border pedagogy: A critical framework for service learning', Michigan Journal of Community Service Learning, vol. 4, pp. 72-80. 
Hodges, D 1998, 'Participation as dis-identification with/in a community of practice', Mind, Culture and Activity, vol. 5, no. 4, pp. 272-290.

Hodkinson, H \& Hodkinson, P 2003, 'Rescuing communities of practice from accusations of idealism: A case study of workplace learning for secondary school teachers in England', paper presented at Experiential: Community: Workbased: Researching learning outside the academy conference, Glasgow University.

Keith, N 1998, 'Community service for community building: The school-based service corps as border crossers', Michigan Journal for Community Service Learning, vol. 5, pp. 86-96.

Keith, N 2005, 'Community service learning in the face of globalisation: Rethinking theory and practice', Michigan Journal for Community Service Learning, Spring, pp. 5-24.

Kozulin, A 1998, Psychological tools: A sociocultural approach to education, Harvard University Press, London.

Lave, J \& Wenger, E 1991, Situated learning: Legitimate peripheral participation, Cambridge University Press, Cambridge.

Lemke, J 1997, 'Cognition, context and learning: A social semiotic perspective', in D Kirshner \& A Whitson (eds), Situated cognition: Social, semiotic, and psychological perspectives, Lawrence Erlbaum Associates, Hillsdale, NJ.

Leont'ev, AN 1981, Problems of the development of the mind, Progress Publishers, Moscow.

McMillan, J \& Shay, S 2004, 'Service learning as "situated learning" in higher education: A conceptual framework', paper prepared as part of the JET-funded service learning project, University of Cape Town.

McMillan, J 2008, 'What happens when the university meets the community? An analysis of service learning as "boundary work" in higher education', unpublished PhD thesis, Department of Sociology, Faculty of Humanities, University of Cape Town.

Moore, D 2000, 'The relationship between experiential learning research and service learning research', Michigan Journal of Community Service Learning, Special Issue Fall, pp. 124-128.

Morton, K \& Troppe, M 1996, 'From the margin to the mainstream: Campus Compact's project on integrating service with academic study', Journal of Business Ethics, vol. 15, no. 1, pp. 21-32.

NCHE (National Commission on Higher Education) 1996, Discussion document: A framework for transformation, Human Sciences Research Council, Pretoria.

Russell, D 2002, 'Looking beyond the interface: Activity theory and distributed learning', in M Lea \& K Nicoll (eds) Distributed learning: Social and cultural approaches to practice, Routledge/Falmer \& the Open University, London, New York.

Scott, I, McMillan, J, Yeld, N \& Hall, M 2003, Equity and excellence in higher education: The case of the University of Cape Town, Report to Mellon Foundation, December.

Skilton-Sylvester, E \& Erwin, E 2000, ‘Creating reciprocal learning relationships across socially-constructed borders', Michigan Journal of Community Service Learning, vol. 7, no. 1, pp. 65-75.

Stanton, T 1998, 'Institutionalizing service learning within postsecondary education: Transformation or social adaptation?', Partnership Perspectives, vol. 1, no. 1, CommunityCampus Partnerships for Health, San Francisco.

Stanton, T, Giles, D \& Cruz, N 1999, Service learning: A movement's pioneers reflect on its origins, practice, and future, Jossey-Bass, San Francisco.

Star, S \& Griesemer, R 1989, 'Institutional ecology, "translations" and boundary objects: Amateurs and professionals in Berkeley's Museum of Vertebrate Zoology, 1907-39', Social Studies of Science, vol. 19, pp. 387-420. 
Taylor, J 2002, 'Metaphors we serve by: Investigating the conceptual metaphors framing national and community service and service learning', Michigan Journal of Community Service Learning, vol. 9, no.1, pp. 45-57.

Tuomi-Gröhn, T \& Engeström, Y (eds) 2003, Between school and work: New perspectives on transfer and boundary-crossing, Pergamon, Amsterdam, New York.

Vygotsky, LS 1978, Mind in society, Harvard University Press, Cambridge, MA.

Waterman, AS (ed.) 1997, Service-learning: Applications from the research, Lawrence Erlbaum Associates, Hillsdale, NJ, London.

Wenger, E 1998, Communities of practice: Learning, meaning and identity, Cambridge University Press, Cambridge.

Wertsch, J 1985, Vygotsky and the social formation of mind, Harvard University Press, Cambridge, MA.

Wolfson, L \& Willinsky, J 1998, 'What service learning can learn from situated learning', Michigan Journal of Community Service Learning, vol. 5, pp. 22-31.

Zlotkowski, E (ed.) 1998, Successful service-learning programs: New models of excellence in higher education, Anker Publishing Company, Bolton, MA. 